\title{
TEKNIK PEMBUATAN DAN SIFAT BRIKET ARANG DARI TEMPURUNG DAN KAYU TANAMAN JARAK PAGAR (Jatropha curcas L.)
}

\author{
(Technical Process and Characteristics of Charcoal Briquette \\ from Jatropha Curcas (Jatropha curcas L) Shell and Wood)
}

\author{
Oleh/By :
}

R. Sudradjat ${ }^{1)}$, D. Setiawan ${ }^{2)} \&$ H. Roliadi ${ }^{1)}$

\begin{abstract}
The aim of this research is to study the use of Jatropha curcas plant wastes in the form of seed shell and wood for making charcoal briquette, to increase economic feasibility of biodiesel manufacturing from jatropha curcas oil.

Treatments used were 200,400 , and $600 \mathrm{~kg} / \mathrm{cm}^{2}$ of compression, composition of raw materials were mixture with coconut shell of 0,25,50,75 and $100 \%$.

The results showed that char-briquette that was made from jatro-shell (100\%) showed higher value in density and compression strength, but lower in moisture, fixed carbon, calorific value from those of char-briquette from jatro-wood $(100 \%)$. On the other hand, char-briquette from jatro-wood was higher in moisture, fixed carbon and calorific value, but lower in density and compression strength. Mixture of those materials with coco-shell could increasing of fixed carbon and calorific value char-briquette from jatro-shell, and also increase density and compression strength of char-briquette from jatro-wood.

Some physico-chemical properties has been met the Japan Standard i.e: compression strength, moisture, volatile matter, fixed carbon (except char-briquette from jatro-shell of B 100/0). Density, ash content and calorific values were beyond the Japan Standard.
\end{abstract}

Keywords: Jatropha shell, jatropha wood, charcoal briquette,calorific value.

\begin{abstract}
ABSTRAK
Penelitian ini bertujuan untuk mempelajari pemanfaatan limbah dari tanaman jarak pagar berupa tempurung biji dan kayu untuk briket arang, yaitu dalam rangka meningkatkan kelayakan ekonomi pengusahaan minyak jarak pagar untuk biodisel.

Perlakuan dalam penelitian ini adalah pemberian tekanan 200, $400 \mathrm{dan} 600 \mathrm{~kg} / \mathrm{cm}^{2}$, serta komposisi campuran bahan baku (tempurung biji dan kayu jarak pagar) dengan tempurung kelapa 0,25 , 50, 75 dan $100 \%$.
\end{abstract}

\footnotetext{
${ }^{1)}$ Peneliti pada Pusat Penelitian dan Pengembangan Hasil Hutan, Bogor

2) Teknisi pada Pusat Penelitian dan Pengembangan Hasil Hutan, Bogor
} 
Hasil penelitian menunjukkan, briket yang dibuat dari tempurung biji jarak pagar (100\%) lebih tinggi di dalam kerapatan dan keteguhan tekan, tetapi lebih rendah di dalam kadar air, karbon terikat dan nilai kalor dari briket dari kayu jarak (100\%). Briket kayu jarak pagar (100\%) sebaliknya lebih tinggi dalam kadar air, karbon terikat dan nilai kalor, tetapi lebih rendah dalam kerapatan dan keteguhan tekan dari briket tempurung biji jarak pagar. Pencampuran dengan tempurung kelapa dapat meningkatkan karbon terikat dan nilai kalor briket dari tempurung biji jarak, serta meningkatkan kerapatan dan keteguhan tekan briket dari kayu jarak pagar.

Beberapa sifat fisiko-kimia briket arang telah memenuhi Standar Jepang yaitu: keteguhan tekan, kadar air, zat terbang, karbon terikat (kecuali briket arang dari tempurung biji jarak B 100/0). Sifat yang tidak memenuhi standar adalah: kerapatan, kadar abu dan nilai kalor (kecuali briket arang dari kayu jarak B 50/50).

Kata kunci: Tempurung biji jarak, kayu jarak pagar, briket arang, nilai kalor.

\section{PENDAHULUAN}

Cadangan bahan bakar fosil seperti minyak bumi, gas alam dan batu bara yang selama ini merupakan sumber utama energi jumlahnya semakin menipis (Indarti, 2001). Hal ini dikhawatirkan akan menyebabkan terjadinya kelangkaan bahan bakar dimasa yang akan datang. Menurut Abdullah (2002), Indonesia dalam waktu 10 - 20 tahun ke depan akan menjadi menjadi negara pengimpor minyak bersih (Net Oil Importing Country) jika kondisi ini tetap dibiarkan dan belum ada upaya-upaya yang signifikan. Demikian pula harga minyak bumi pada tahun 2005 tercatat memiliki rekor tertinggi dalam sejarah harga minyak dunia yaitu US\$ 70. Situasi ini memacu para peneliti untuk mencari sumber energi alternatif lain yang dapat dipulihkan dan secara potensial dapat dikembangkan di Indonesia, di antaranya adalah minyak dari biji tanaman jarak pagar (Jatropha curcas L). Lubis dan Sugiyono (1996), menyatakan bahwa sektor energi memiliki peran yang sangat penting dalam rangka mendukung kelangsungan proses pembangunan nasional.

Sudradjat et al. (2004), telah berhasil mengetahui cara proses dan karakteristik minyak (curcas oil) dan biodisel dari minyak jarak pagar. Dalam rangka mengantisipasi kemungkinan pengembangan tanaman ini secara luas di Indonesia sebagai bahan energi alternatif, maka perlu diketahui pemanfaatan bagian lain dari tanaman ini yang potensial sebagai bahan energi berupa briket arang. Berdasarkan penelitian sebelumnya diketahui bahwa tempurung biji jarak pagar memiliki porsi sekitar 25\% dari berat biji tersebut. Artinya dari produksi sekitar 3 ton biji kering/ha akan dihasilkan sekitar 1 ton tempurung, sedang kayu jarak dapat diperoleh dari pangkasan secara periodik setahun sekali. Sudradjat et al. (2004), menemukan bahwa tempurung jarak pagar sangat baik dan memenuhi standar kualitas internasional untuk dibuat arang aktif, sedang arang aktif kayunya cukup baik hanya untuk daya serap terhadap larutan (daya serap iod).

Pembuatan briket arang dapat dilakukan dengan cara penambahan perekat tapioka, dimana bahan baku diarangkan terlebih dahulu kemudian ditumbuk, dicampur perekat dan dicetak (kempa dingin) dengan sistim hidrolik manual dan selanjutnya dikeringkan (Pari, 2002). Perekat pati dalam bentuk cair sebagai bahan perekat menghasilkan briket arang bernilai rendah dalam hal kerapatan, keteguhan tekan, kadar abu dan zat mudah menguap, tetapi akan lebih tinggi dalam hal kadar air, karbon terikat dan nilai kalornya apabila 
dibandingkan dengan briket arang yang menggunakan perekat molase atau tetes tebu (Sudradjat, 1983). Menurut Sa'id (1996), apabila dibandingkan dengan arang, briket arang memiliki beberapa keunggulan antara lain dapat ditingkatkan kerapatannya, bentuk dan ukurannya dapat disesuaikan, tidak kotor, mudah diangkut dan praktis sebagai bahan bakar.

\section{METODOLOGI}

\section{A. Pembuatan Arang}

Pembuatan arang dilakukan dalam kiln berbentuk silinder berkapasitas 200 liter yang terbuat dari besi bekas drum. Pembuatan arang dari tempurung dilakukan secara terpisah dari pada kayunya. Selain tempurung dan kayu jarak pagar, sebagai pencampur dan penguat briket digunakan juga bahan baku lain yaitu tempurung kelapa.

Sebelum bahan baku dimasukkan ke dalam kiln, terlebih dahulu batang kayu/bambu berdiameter $10 \mathrm{~cm}$ dan panjang $100 \mathrm{~cm}$ ditempatkan tegak lurus pada titik tengah landasan kiln. Bahan baku dimasukkan sampai memenuhi dan memadati rongga kiln, selanjutnya kayu dicabut sehingga terbentuk lubang di bagian tengah kiln. Lubang ini adalah sebagai tempat bahan bakar umpan agar bahan baku terbakar dan menyala.

Bahan bakar umpan dinyalakan, dan setelah api menyala dengan stabil, kiln ditutup lalu cerobong asap dipasang pada bagian tengah kiln tersebut. Selanjutnya dilakukan pengaturan buka tutup lubang udara pada dinding kiln dan pembakaran terus dilakukan sampai asap yang keluar menipis dan berwarna kebiruan. Setelah itu lubang udara ditutup seluruhnya dan proses pirolisa tanpa udara dibiarkan terus berlanjut sampai sekitar 4 - 6 jam. Setelah cukup waktunya, arang dikeluarkan dan disiram dengan air. Prosedur ini dilakukan untuk setiap jenis bahan baku yaitu tempurung dan kayu jarak pagar serta tempurung kelapa.

\section{B. Pembuatan Serbuk dan Penyaringan}

Arang digiling dalam mesin giling kayu hingga terbentuk serbuk yang cukup, sedang yang sangat halus akan terbang dan ditangkap oleh siklun dan ditampung terpisah. Selanjutnya serbuk arang disaring dan hanya ukuran serbuk yang lolos 20 mesh dan tertampung pada 40 mesh yang digunakan untuk pembuatan briket arang.

\section{Pencampuran Perekat}

Perekat yang digunakan adalah tepung tapioka yang terlebih dahulu dibuat menjadi kanji yaitu dengan jalan mencampur dengan air secukupnya dan memanaskan di atas api sampai tepung berubah menjadi kanji. Banyaknya tepung tapioka adalah 5\% dari berat kering briket arang yaitu untuk berat briket sekitar 50 gram per buah. Selanjutnya kanji dicampur dengan serbuk arang sampai menjadi adonan yang merata.

\section{Pengempaan Briket}

Adonan dimasukkan ke dalam alat cetakan, kemudian dikempa menggunakan alat kempa hidraulik manual dengan variasi tekanan 200, 400 dan $600 \mathrm{~kg} / \mathrm{cm}^{2}$. Selanjutnya briket arang yang masih basah dikeringkan dalam oven pada suhu $60^{\circ} \mathrm{C}$ selama 24 jam. 


\section{E. Pengujian Kualitas}

Kualitas briket yang diuji meliputi sifat kimia dan fisik terdiri dari kadar air, kadar abu, kadar zat menguap, kadar karbon terikat, kerapatan, keteguhan tekan (ASTM, 1959) dan nilai kalor (ASTM, 1984).

\section{F. Rancangan Penelitian}

Jenis bahan baku yang digunakan adalah tempurung biji jarak pagar dan kayu jarak pagar. Untuk setiap jenis bahan baku diberikan perlakuan yaitu komposisi (A) persentase antara tempurung biji jarak pagar dengan tempurung kelapa serta persentase antara kayu jarak pagar dengan tempurung kelapa sebagai berikut:
$\mathrm{A} 1=\mathrm{BBJ}: \mathrm{TK}=0 \%: 100 \%$
$\mathrm{A} 4=\mathrm{BBJ}: \mathrm{TK}=75 \%: 25 \%$
$\mathrm{A} 2=\mathrm{BBJ}: \mathrm{TK}=100 \%: 0 \%$
$\mathrm{A} 5=\mathrm{BBJ}: \mathrm{TK}=25 \%: 75 \%$
$\mathrm{A} 3=\mathrm{BBJ}: \mathrm{TK}=50 \%: 50 \%$

di mana: $\mathrm{BBJ}=$ Bahan baku jarak (Tempurung atau kayu) dan TK $=$ Tempurung kelapa.

Untuk setiap taraf perlakuan diberikan variable perlakuan yaitu tekanan pengempaan (B) $: \mathrm{B} 1=200 \mathrm{~kg} / \mathrm{cm}^{2}, \mathrm{~B} 2=400 \mathrm{~kg} / \mathrm{cm}^{2}$ dan B3 $=600 \mathrm{~kg} / \mathrm{cm}^{2}$. Jumlah ulangan $3 \mathrm{kali}$. Jumlah total kombinasi perlakuan adalah 90. Rancangan penelitian yang digunakan adalah Rancangan Acak Berblok dengan Percobaan Faktorial, khususnya untuk parameter sifat fisis-mekanis briket yaitu kerapatan dan keteguhan tekan. Untuk parameter pengamatan sifat fisiko-kimia briket yaitu kadar air, abu, zat terbang, karbon terikat dan nilai kalor dilakukan analisis cara evaluasi tabulasi dan uji beda jarak Tukey atau uji beda nyata jujur (BNJ) dilanjutkan dengan nilai skoring (Steel \& Torrie, 1995).

\section{HASIL DAN PEMBAHASAN}

\section{A. Tempurung Biji Jarak Pagar}

\section{Kerapatan}

Hasil analisa sidik ragam menunjukan nilai kerapatan berkisar antara 0,19-0,21 g/ $\mathrm{cm}^{2}$ (Tabel 1). Hasil uji sidik ragam menunjukkan perlakuan persentase campuran tempurung kelapa dan perlakuan pengempaan berpengaruh nyata pada kerapatan (taraf kepercayaan 5\%). Hasil uji beda nyata jujur menunjukkan kerapatan tertinggi diperoleh dari bahan baku tempurung biji jarak 100\% dengan tekanan kempa $600 \mathrm{~kg} / \mathrm{cm}^{2}$, tempurung kelapa 100\% dengan tekanan kempa $600 \mathrm{~kg} / \mathrm{cm}^{2}$ dan campuran tempurung kelapa 50\% dengan tekanan kempa $600 \mathrm{~kg} / \mathrm{cm}^{2}$. Komposisi bahan baku dengan berbagai variasi tekanan kempa yang menghasilkan kerapatan rata-rata tertinggi adalah tempurung kelapa 100\%, serta sedikit lebih rendah kerapatan dihasilkan oleh tempurung biji jarak 100\% dan campuran tempurung kelapa $50 \%$. 
Tabel1. Nilai rata-rata dan hasil uji BNJ kerapatan briket tempurung biji jarak pagar Table 1. Average values and HSD-tests of density of jatropha shell briquette

\begin{tabular}{|c|c|c|c|c|}
\hline $\begin{array}{c}\text { Komposisi } \\
\text { (Composition), A }\end{array}$ & $\begin{array}{c}\text { Tekanan } \\
\text { (Compression) } \\
\mathrm{kg} / \mathrm{cm}^{2}, \mathrm{~B}\end{array}$ & $\begin{array}{c}\text { Kode perlakuan } \\
\text { (Treatment codes) } \\
\mathrm{T}\end{array}$ & $\begin{array}{l}\text { Nilai kerapatan } \\
\text { (Density), } \mathrm{g} / \mathrm{cm}^{2}\end{array}$ & $\begin{array}{l}\text { Skor } \\
\text { (Score) }\end{array}$ \\
\hline A 1 & $\begin{array}{ll}\text { B } & 1 \\
\text { B } & 2 \\
\text { B } & 3\end{array}$ & $\begin{array}{l}\text { T } 1 \\
\text { T } 2 \\
\text { T } 3\end{array}$ & $\begin{array}{r}0,19 \quad \mathrm{c} \\
0,20 \mathrm{bc} \\
0,21 \quad \mathrm{a}\end{array}$ & $\begin{array}{c}2 \\
2,5 \\
4\end{array}$ \\
\hline A 2 & $\begin{array}{l}\text { B } 1 \\
\text { B } 2 \\
\text { B } 3\end{array}$ & $\begin{array}{l}\text { T } 4 \\
\text { T } 5 \\
\text { T } 6\end{array}$ & $\begin{array}{cc}0,20 & \text { abc } \\
0,21 & a b \\
0,21 & a\end{array}$ & $\begin{array}{c}3 \\
2,5 \\
4\end{array}$ \\
\hline A 3 & $\begin{array}{l}\text { B } 1 \\
\text { B } 2 \\
\text { B } 3\end{array}$ & $\begin{array}{l}\text { T } 7 \\
\text { T } 8 \\
\text { T } 9\end{array}$ & $\begin{array}{rr}0,19 & \mathrm{c} \\
0,20 & \mathrm{bc} \\
0,21 & \mathrm{a}\end{array}$ & $\begin{array}{c}2 \\
2,5 \\
4\end{array}$ \\
\hline A 4 & $\begin{array}{l}\text { B } 1 \\
\text { B } 2 \\
\text { B } 3\end{array}$ & $\begin{array}{l}\text { T } 10 \\
\text { T } 11 \\
\text { T } 12\end{array}$ & $\begin{array}{l}0,19 \quad \mathrm{c} \\
0,20 \text { abc } \\
0,20 \text { abc }\end{array}$ & $\begin{array}{l}2 \\
3 \\
3\end{array}$ \\
\hline A 5 & $\begin{array}{l}\text { B } 1 \\
\text { B } 2 \\
\text { B } 3\end{array}$ & $\begin{array}{l}\text { T } 13 \\
\text { T } 14 \\
\text { T } 15\end{array}$ & $\begin{array}{l}0,19 \quad \mathrm{c} \\
0,20 \mathrm{c} \\
0,20 \mathrm{ab}\end{array}$ & $\begin{array}{c}2 \\
2,5 \\
3,5\end{array}$ \\
\hline
\end{tabular}

Keterangan (Remarks) : Nilai skor total dihasilkan dari perhitungan menurut asumsi nilai skor a $=4$; b $=3 ; \mathrm{c}=2$ dan $\mathrm{d}=1$. A1 $=$ tempurung biji jarak pagar 100\%; A2 = tempurung kelapa $100 \% ; \mathrm{A} 3=$ tempurung biji jarak 50\% dan tempurung kelapa 50\%; A4 = tempurung biji jarak $75 \%$ dan tempurung kelapa 25\%; A5 = tempurung biji jarak $25 \%$ dan tempurung kelapa $75 \%$. B1 $=$ tekanan $200 \mathrm{~kg} / \mathrm{cm}^{2} ; \mathrm{B} 2=400 \mathrm{~kg} / \mathrm{cm}^{2}$ dan B3 $=600 \mathrm{~kg} / \mathrm{cm}^{2}$ (Total score achieved based on calculation with assumptions that a score $=4 ; b=3 ; c=2$ and $d=1 . A 1=J a t r o p h a$ seed shell 100\%;A2 = Coconut shell 100\%; $A 3=$ Jatropha seed shell: coco-shell $=50 \%: 50 \% ; A 4=$ Jatropha seed shell: coco-shell $=75 \%: 25 \% ; A 5=$ Jatropha seed shell: coco-shell $=25 \%: 75 \% . \quad B 1=$ compression of $200 \mathrm{~kg} / \mathrm{cm}^{2}, B 2=400 \mathrm{~kg} / \mathrm{cm}^{2}$, and B3 $=600 \mathrm{~kg} / \mathrm{cm}^{2}$, respectively).

\section{Keteguhan tekan}

Hasil analisa sidik ragam menunjukkan nilai keteguhan tekan berkisar antara 768,00 $1910,60 \mathrm{~kg} / \mathrm{cm}^{2}$ (Tabel 2). Hasil uji sidik ragam menunjukkan perlakuan persentase campuran tempurung kelapa dan perlakuan pengempaan berpengaruh nyata pada keteguhan tekan (taraf kepercayaan 5\%). Hasil uji beda nyata jujur menunjukkan keteguhan tekan tertinggi diperoleh dari bahan baku tempurung biji jarak 100\% dengan tekanan kempa $600 \mathrm{~kg} / \mathrm{cm}^{2}$, campuran dengan tempurung kelapa 50\% pada tekanan kempa 400 dan $600 \mathrm{~kg} / \mathrm{cm}^{2}$, dan campuran dengan tempurung kelapa $75 \%$ pada tekanan kempa $600 \mathrm{~kg} / \mathrm{cm}^{2}$. Komposisi bahan baku dengan berbagai variasi tekanan kempa yang menghasilkan keteguhan tekan rata- 
rata tertinggi adalah tempurung biji jarak 50\% dengan tempurung kelapa 50\%, serta sedikit lebih rendah adalah komposisi tempurung biji jarak 100\% dan campuran dengan tempurung kelapa $75 \%$.

\section{Sifat fisiko-kimia briket arang tempurung biji jarak pagar}

Hasil analisis sifat fisiko-kimia briket arang yang dibuat dari campuran tempurung biji jarak pagar dan tempurung kelapa terlihat pada Tabel3.

Tabel2. Nilai rata-rata dan hasil uji BNJ keteguhan tekan briket tempurung biji jarak pagar

Table 2. Average values and HSD-tests of compression strength of jatropha shell briquette

\begin{tabular}{|c|c|c|c|c|}
\hline $\begin{array}{c}\text { Komposisi } \\
\text { (Composition), A }\end{array}$ & $\begin{array}{c}\text { Tekanan } \\
\text { (Compression) } \\
\mathrm{kg} / \mathrm{cm}^{2}, \mathrm{~B}\end{array}$ & $\begin{array}{c}\text { Kode perlakuan } \\
\text { (Treatment codes) } \\
\mathrm{T}\end{array}$ & $\begin{array}{c}\text { Keteguhan } \\
\text { tekan (Compression } \\
\text { strength), } \mathrm{kg} / \mathrm{cm}^{2}\end{array}$ & $\begin{array}{l}\text { Skor } \\
\text { (Score) }\end{array}$ \\
\hline A 1 & $\begin{array}{ll}\text { B } & 1 \\
\text { B } & 2 \\
\text { B } & 3\end{array}$ & $\begin{array}{l}\text { T1 } \\
\text { T } 2 \\
\text { T } 3\end{array}$ & $\begin{array}{l}1553,30 \quad \mathrm{c} \\
1746,67 \mathrm{ab} \\
1820,00 \quad \mathrm{a}\end{array}$ & $\begin{array}{c}4 \\
5,5 \\
6\end{array}$ \\
\hline A 2 & $\begin{array}{l}\text { B } 1 \\
\text { B } 2 \\
\text { B } 3\end{array}$ & $\begin{array}{l}\text { T } 4 \\
\text { T } 5 \\
\text { T } 6\end{array}$ & $\begin{array}{l}768,00 \mathrm{f} \\
854,60 \mathrm{f} \\
1169,70 \mathrm{f}\end{array}$ & $\begin{array}{l}1 \\
1 \\
2\end{array}$ \\
\hline A 3 & $\begin{array}{ll}\text { B } & 1 \\
\text { B } & 2 \\
\text { B } & 3\end{array}$ & $\begin{array}{l}\text { T } 7 \\
\text { T } 8 \\
\text { T } 9\end{array}$ & $\begin{array}{c}1570,60 \quad \mathrm{bc} \\
1789,30 \quad \mathrm{a} \\
1910,60 \quad \mathrm{a}\end{array}$ & $\begin{array}{c}4,5 \\
6 \\
6\end{array}$ \\
\hline A 4 & $\begin{array}{l}\text { B } 1 \\
\text { B } 2 \\
\text { B } 3\end{array}$ & $\begin{array}{l}\text { T } 10 \\
\text { T } 11 \\
\text { T } 12\end{array}$ & $\begin{array}{l}10481,00 \mathrm{e} \\
1097,30 \mathrm{e} \\
1354,60 \mathrm{~d}\end{array}$ & $\begin{array}{l}2 \\
2 \\
3\end{array}$ \\
\hline A 5 & $\begin{array}{ll}\text { B } & 1 \\
\text { B } & 2 \\
\text { B } & 3\end{array}$ & $\begin{array}{l}\text { T } 13 \\
\text { T } 14 \\
\text { T } 15\end{array}$ & $\begin{array}{l}1508,00 \mathrm{~cd} \\
1745,30 \mathrm{ab} \\
1089,30 \mathrm{a}\end{array}$ & $\begin{array}{c}3,5 \\
5,5 \\
6\end{array}$ \\
\hline
\end{tabular}

Keterangan (Remarks) : Nilai skor total dihasilkan dari perhitungan menurut asumsi nilai skor a $=6$; $\mathrm{b}$ $=5 ; \quad \mathrm{c}=4 ; \mathrm{d}=3 ; \quad \mathrm{e}=2 \mathrm{dan} \mathrm{f}=1 . \quad \mathrm{A} 1=$ tempurung biji jarak pagar $100 \% ; \mathrm{A} 2=$ tempurung kelapa $100 \%$; A3; tempurung biji jarak 50\% dan tempurung kelapa 50\%; A4 $=$ tempurung biji jarak $75 \%$ dan tempurung kelapa $25 \%$; A $5=$ tempurung biji jarak $25 \%$ dan tempurung kelapa $75 \%$. B1 $=$ tekanan $200 \mathrm{~kg} / \mathrm{cm}^{2} ; \mathrm{B} 2=400 \mathrm{~kg} / \mathrm{cm}^{2}$ dan B3 $=600$ $\mathrm{kg} / \mathrm{cm}^{2}$ (Total score achieved based on calculation with assumptions that a score $=6 ; b=5 ; c=4 ; d=$ $3 ; e=2$ and $=1$. A1 = Jatropha seed shell 100\%;A2 = Coconut shell 100\%;A3= Jatropha seed shell: coco-shell $=50 \%: 50 \% ;$ A4 = Jatropha seed shell: coco-shell $=75 \%: 25 \% ;$ A5 = Jatropha seed shell: coco-shell $=25 \%: 75 \% . B 1=$ compression of $200 \mathrm{~kg} / \mathrm{cm}^{2}, B 2=400 \mathrm{~kg} / \mathrm{cm}^{2}$, and B3 $=600$ $\mathrm{kg} / \mathrm{cm}^{2}$, respectively). 
Tabel3. Nilai rata-rata dan hasil uji BNJ sifat fisiko-kimia briket arang dari tempurung jarak pagar

Table 3. Average values and HSD-tests of physico-chemical properties of jatropha shell briquette

\begin{tabular}{|c|c|c|c|c|c|c|}
\hline $\begin{array}{c}\text { Komposisi } \\
\text { (Composition) } \\
\text { A }\end{array}$ & $\begin{array}{c}\text { Tekanan } \\
\text { (Compression) } \\
\mathrm{kg} / \mathrm{cm}^{2} \\
\mathrm{~B}\end{array}$ & $\begin{array}{c}\text { Kadar air } \\
\text { (Moisture) } \\
\%\end{array}$ & $\begin{array}{c}\text { Zat terbang } \\
\text { (Volatile) } \\
\%\end{array}$ & $\begin{array}{c}\text { Kadar abu } \\
(A s h) \\
\%\end{array}$ & $\begin{array}{c}\text { Karbon } \\
\text { terikat } \\
\text { (F. carbon) } \\
\%\end{array}$ & $\begin{array}{c}\text { Nilai kalor } \\
\text { (Calorific } \\
\text { val.) } \\
\mathrm{cal} / \mathrm{g}\end{array}$ \\
\hline A 1 & $\begin{array}{l}\text { B } 1 \\
\text { B } 2 \\
\text { B } 3\end{array}$ & $\begin{array}{c}2,60 \mathrm{bc} \\
2,92 \mathrm{~b} \\
1,74 \mathrm{def}\end{array}$ & $\begin{array}{c}25,40 \mathrm{ab} \\
26,74 \mathrm{a} \\
26,65 \mathrm{a}\end{array}$ & $\begin{array}{c}17,17 \mathrm{a} \\
16,41 \mathrm{ab} \\
17,92 \mathrm{a}\end{array}$ & $\begin{array}{l}57,43 \mathrm{gh} \\
56,85 \mathrm{~h} \\
55,43 \mathrm{~h}\end{array}$ & $\begin{array}{l}4855 \mathrm{j} \\
4835 \mathrm{j} \\
4758 \mathrm{k}\end{array}$ \\
\hline Rata-rata: & & $2,42 \mathrm{a}$ & $26,26 \mathrm{a}$ & $17,17 \mathrm{a}$ & $56,57 \mathrm{e}$ & $4816 \mathrm{e}$ \\
\hline A 2 & $\begin{array}{l}\text { B } 1 \\
\text { B } 2 \\
\text { B } 3\end{array}$ & $\begin{array}{c}1,74 \mathrm{def} \\
2,21 \mathrm{~cd} \\
3,15 \mathrm{~b}\end{array}$ & $\begin{array}{c}19,76 \mathrm{e} \\
19,09 \mathrm{e} \\
20,06 \mathrm{de}\end{array}$ & $\begin{array}{l}2,97 \mathrm{f} \\
2,11 \mathrm{f} \\
3,05 \mathrm{f}\end{array}$ & $\begin{array}{l}77,27 \mathrm{ab} \\
79,80 \mathrm{a} \\
76,89 \mathrm{~b}\end{array}$ & $\begin{array}{l}6846 \mathrm{a} \\
6746 \mathrm{~b} \\
6601 \mathrm{c}\end{array}$ \\
\hline Rata-rata: & & $2,37 \mathrm{a}$ & $19,30 \mathrm{~d}$ & $2,71 \mathrm{~d}$ & $77,99 \mathrm{a}$ & $6731 \mathrm{a}$ \\
\hline A 3 & $\begin{array}{ll}\text { B } & 1 \\
\text { B } & 2 \\
\text { B } & 3\end{array}$ & $\begin{array}{c}1,20 \mathrm{f} \\
1,51 \mathrm{ef} \\
2,04 \mathrm{cde}\end{array}$ & $\begin{array}{l}24,44 \mathrm{~b} \\
23,76 \mathrm{bc} \\
21,81 \mathrm{~cd}\end{array}$ & $\begin{array}{l}13,02 \mathrm{~d} \\
13,78 \mathrm{~cd} \\
12,84 \mathrm{~d}\end{array}$ & $\begin{array}{c}62,54 \mathrm{f} \\
63,46 \mathrm{f} \\
68,35 \mathrm{ed}\end{array}$ & $\begin{array}{l}5727 \mathrm{f} \\
5576 \mathrm{~g} \\
5566 \mathrm{~g}\end{array}$ \\
\hline Rata-rata: & & $1,58 \mathrm{~b}$ & $23,34 \mathrm{c}$ & $13,21 \mathrm{~b}$ & $64,78 \mathrm{c}$ & $5623 \mathrm{c}$ \\
\hline A 4 & $\begin{array}{l}\text { B } 1 \\
\text { B } 2 \\
\text { B } 3\end{array}$ & $\begin{array}{c}1,88 \mathrm{de} \\
1,16 \mathrm{f} \\
4,23 \mathrm{a}\end{array}$ & $\begin{array}{l}25,00 \mathrm{ab} \\
25,33 \mathrm{ab} \\
25,33 \mathrm{ab}\end{array}$ & $\begin{array}{c}15,29 \mathrm{bc} \\
8,60 \mathrm{e} \\
17,28 \mathrm{a}\end{array}$ & $\begin{array}{c}59,81 \mathrm{~g} \\
66,07 \mathrm{e} \\
57,39 \mathrm{gh}\end{array}$ & $\begin{array}{l}5095 \mathrm{~h} \\
5027 \mathrm{hi} \\
4975 \mathrm{i}\end{array}$ \\
\hline Rata-rata: & & $2,42 \mathrm{a}$ & $25,22 \mathrm{~b}$ & $13,72 \mathrm{~b}$ & $61,09 \mathrm{~d}$ & $5032 \mathrm{~d}$ \\
\hline A 5 & $\begin{array}{l}\text { B } 1 \\
\text { B } 2 \\
\text { B } 3\end{array}$ & $\begin{array}{l}1,17 \mathrm{f} \\
1,48 \mathrm{ef} \\
1,55 \mathrm{ef}\end{array}$ & $\begin{array}{l}21,07 \mathrm{~d} \\
20,82 \mathrm{de} \\
20,89 \mathrm{de}\end{array}$ & $\begin{array}{l}7,95 \mathrm{e} \\
8,01 \mathrm{e} \\
8,55 \mathrm{e}\end{array}$ & $\begin{array}{c}70,98 \mathrm{c} \\
71,17 \mathrm{c} \\
70,56 \mathrm{~cd}\end{array}$ & $\begin{array}{l}6143 \mathrm{~d} \\
6092 \mathrm{~d} \\
6011 \mathrm{e}\end{array}$ \\
\hline Rata-rata: & & $1,40 \mathrm{~b}$ & $20,93 \mathrm{~d}$ & $8,17 \mathrm{c}$ & $70,90 \mathrm{~b}$ & $6082 \mathrm{~b}$ \\
\hline
\end{tabular}

Keterangan (Remarks) : Nilai skor total dihasilkan dari perhitungan menurut asumsi nilai skor a $=9$; $\mathrm{b}$ $=8 ; \mathrm{c}=7 ; \mathrm{d}=6 ; \mathrm{e}=5 ; \mathrm{f}=4 ; \mathrm{g}=3 ; \mathrm{h}=2$ dan $\mathrm{i}=1 . \mathrm{A} 1=$ tempurung biji jarak pagar $100 \% ;$ A2 $=$ tempurung kelapa $100 \% ; \quad$ A $3=$ tempurung biji jarak pagar $50 \%$ dan tempurung kelapa 50\%; A $4=$ tempurung biji jarak pagar $75 \%$ dan tempurung kelapa $25 \%$; A5 = tempurung biji jarak pagar 25\% dan tempurung kelapa 75\%. B1 = tekanan 200 $\mathrm{kg} / \mathrm{cm}^{2} ; \mathrm{B} 2=400 \mathrm{~kg} / \mathrm{cm}^{2}$ dan B3 $=600 \mathrm{~kg} / \mathrm{cm}^{2}$ (Total score achieved based on calculation with assumptions that a score $=9 ; b=8 ; c=7 ; d=6 ; e=5 ; f=4 ; g=3 ; b=2$ and $i=1$. A1 = Jatropha seed shell 100\%;A2 = Coconut shell 100\%;A3 = Jatropha seed shell: coco-shell $=50 \%: 50 \% ; A 4=$ Jatropha seed shell: coco-shell $=75 \%: 25 \% ; A 5=$ Jatropha seed shell: coco-shell $=25 \%: 75 \% . \quad B 1=$ compression of $200 \mathrm{~kg} / \mathrm{cm}^{2}, B 2=400 \mathrm{~kg} / \mathrm{cm}^{2}$, and B3 $=600 \mathrm{~kg} / \mathrm{cm}^{2}$, respectively). 
Hasil tabulasi menunjukkan kadar air berkisar antara 1,16 - 4,20\%. Hasil uji beda t-test menunjukkan kadar air terendah diperoleh dari campuran tempurung kelapa 75\%. Kombinasi bahan baku dan tekanan yang memberikan kadar air terendah diperoleh dari campuran tempurung kelapa $25 \%$ pada tekanan $400 \mathrm{~kg} / \mathrm{cm}^{2}$. Kadar zat terbang berkisar antara 19,09 - 26,74\%. Hasil uji beda t-test menunjukkan kadar zat terbang terendah diperoleh dari bahan baku tempurung kelapa 100\%. Kombinasi bahan baku dan tekanan yang memberikan kadar zat terbang terendah diperoleh dari tempurung kelapa 100\% pada tekanan $400 \mathrm{~kg} / \mathrm{cm}^{2}$. Kadar abu berkisar antara 2,11 - 17,90\%. Hasil uji beda t-test menunjukkan kadar abu terendah diperoleh dari bahan baku tempurung kelapa 100\%. Kombinasi bahan baku dan tekanan yang memberikan kadar abu terendah diperoleh dari tempurung kelapa $100 \%$ pada tekanan $400 \mathrm{~kg} / \mathrm{cm}^{2}$. Kadar karbon terikat berkisar antara 55,43-79,80\%. Hasil uji beda t-test menunjukkan kadar karbon terikat tertinggi diperoleh dari bahan baku tempurung kelapa 100\%. Kombinasi bahan baku dan tekanan yang memberikan kadar karbon terikat tertinggi diperoleh dari tempurung kelapa 100\% pada tekanan $400 \mathrm{~kg} / \mathrm{cm}^{2}$. Nilai kalor berkisar antara 4758 - $6846 \mathrm{kal} / \mathrm{g}$. Hasil uji beda t-test menunjukkan nilai kalor tertinggi diperoleh dari bahan baku tempurung kelapa 100\%. Kombinasi bahan baku dan tekanan yang memberikan nilai kalor tertinggi diperoleh dari tempurung kelapa 100\% pada tekanan $200 \mathrm{~kg} / \mathrm{cm}^{2}$.

\section{B. Kayu Jarak Pagar}

\section{Kerapatan}

Hasil analisa sidik ragam menunjukan nilai kerapatan berkisar antara 0,14-0,21 g/ cm². Hasil uji sidik ragam menunjukkan perlakuan persentase campuran tempurung kelapa dan perlakuan pengempaan berpengaruh nyata pada kerapatan (taraf kepercayaan 5\%). Hasil uji beda nyata jujur menunjukkan kerapatan tertinggi diperoleh dari bahan baku tempurung kelapa 100\% dengan tekanan kempa $600 \mathrm{~kg} / \mathrm{cm}^{2}$. Jenis bahan baku dengan berbagai variasi tekanan kempa yang memberikan nilai rata-rata kerapatan tertinggi adalah bahan baku tempurung kelapa $100 \%$. 
Tabel 4. Nilai rata-rata dan hasil uji BNJ kerapatan briket kayu jarak pagar Table 4. Average values and HSD-tetst of density of Jatropha wood briquette

\begin{tabular}{|c|c|c|c|c|}
\hline $\begin{array}{c}\text { Komposisi } \\
\text { (Composition) } \\
\text { A }\end{array}$ & $\begin{array}{c}\text { Tekanan } \\
\text { (Compression) } \\
\mathrm{kg} / \mathrm{cm}^{2}, \mathrm{~B}\end{array}$ & $\begin{array}{c}\text { Kode perlakuan } \\
\text { (Treatment codes) } \\
\mathrm{T}\end{array}$ & $\begin{array}{c}\text { Nilai kerapatan } \\
\text { (Density) } \\
\mathrm{g} / \mathrm{cm}^{2}\end{array}$ & $\begin{array}{l}\text { Skor } \\
\text { (Score) }\end{array}$ \\
\hline A 1 & $\begin{array}{ll}\text { B } & 1 \\
\text { B } & 2 \\
\text { B } & 3\end{array}$ & $\begin{array}{l}1 \\
2 \\
3\end{array}$ & $\begin{array}{l}0,14 \text { g } \\
0,15 \text { bc } \\
0,16 \text { ef }\end{array}$ & $\begin{array}{c}1 \\
5,5 \\
2,5\end{array}$ \\
\hline A 2 & $\begin{array}{ll}\text { B } & 1 \\
\text { B } & 2 \\
\text { B } & 3\end{array}$ & $\begin{array}{l}4 \\
5 \\
6\end{array}$ & $\begin{array}{rr}0,20 & \mathrm{ab} \\
0,21 & \mathrm{a} \\
0,21 & \mathrm{a}\end{array}$ & $\begin{array}{c}6,5 \\
7 \\
7\end{array}$ \\
\hline A 3 & $\begin{array}{ll}\text { B } & 1 \\
\text { B } & 2 \\
\text { B } & 3\end{array}$ & $\begin{array}{l}7 \\
8 \\
9\end{array}$ & $\begin{array}{ll}0,17 & \mathrm{de} \\
0,18 & \mathrm{~cd} \\
0,18 & \mathrm{~cd}\end{array}$ & $\begin{array}{l}3,5 \\
4,5 \\
4,5\end{array}$ \\
\hline A 4 & $\begin{array}{ll}\text { B } & 1 \\
\text { B } & 2 \\
\text { B } & 3\end{array}$ & $\begin{array}{l}10 \\
11 \\
12\end{array}$ & $\begin{array}{ll}0,14 & g \\
0,15 & \mathrm{fg} \\
0,16 \mathrm{f}\end{array}$ & $\begin{array}{c}1 \\
1,5 \\
2\end{array}$ \\
\hline A 5 & $\begin{array}{ll}\text { B } & 1 \\
\text { B } & 2 \\
\text { B } & 3\end{array}$ & $\begin{array}{l}13 \\
14 \\
15\end{array}$ & $\begin{array}{l}0,17 \text { de } \\
0,18 \mathrm{~cd} \\
0,19 \mathrm{bc}\end{array}$ & $\begin{array}{l}3,5 \\
4,5 \\
5,5\end{array}$ \\
\hline
\end{tabular}

Keterangan (Remarks) : Nilai skor total dihasilkan dari perhitungan menurut asumsi nilai skor a $=7$; b $=6 ; \mathrm{c}=5 ; \mathrm{d}=4 ; \mathrm{e}=3 ; \mathrm{f}=2 \mathrm{dan} \mathrm{g}=1$. A1 = tempurung biji jarak pagar $100 \% ; \mathrm{A} 2=$ tempurung kelapa 100\%; A3 = tempurung biji jarak 50\% dan tempurung kelapa 50\%; A4 $=$ tempurung biji jarak 75\% dan tempurung kelapa 25\%; A5 = tempurung biji jarak 25\% dan tempurung kelapa 75\%. B1 = tekanan $200 \mathrm{~kg} / \mathrm{cm}^{2} ;$ B2 $=400 \mathrm{~kg} / \mathrm{cm}^{2}$ dan B3 = 600 $\mathrm{kg} / \mathrm{cm}^{2}$ (Total score achieved based on calculation with assumptions that a score $=7 ; b=6 ; c=5 ; d=$ 4; $e=3 ; f=2$ and $g=1$. A1 = Jatropha seed shell 100\%; A2 = Coconut shell 100\%; A3= Jatropha seed shell: coco-shell $=50 \%: 50 \% ; A 4=$ Jatropha seed shell: coco-shell $=75 \%: 25 \% ; A 5=$ Jatropha seed shell: coco-shell $=25 \%: 75 \%$. B1 $=$ compression of $200 \mathrm{~kg} / \mathrm{cm}^{2}, B 2=400 \mathrm{~kg} / \mathrm{cm}^{2}$, and $B 3=600 \mathrm{~kg} / \mathrm{cm}^{2}$, respectively).

\section{Keteguhan tekan}

Hasil analisa sidik ragam menunjukan nilai keteguhan tekan berkisar antara 576,00 $1169,70 \mathrm{~kg} / \mathrm{cm}^{2}$ (Tabel 5). Hasil uji sidik ragam menunjukkan perlakuan persentase campuran tempurung kelapa dan perlakuan pengempaan berpengaruh nyata pada keteguhan tekan (taraf kepercayaan 5\%). Hasil uji beda nyata jujur menunjukkan keteguhan tekan tertinggi diperoleh dari bahan baku tempurung biji jarak 100\% dengan tekanan kempa $600 \mathrm{~kg} / \mathrm{cm}^{2}$, komposisi dengan campuran tempurungh kelapa 50\% pada tekanan $400 \mathrm{dan} 600 \mathrm{~kg} / \mathrm{cm}^{2}$ dan komposisi dengan campuran tempurung kelapa 75\% pada tekanan $600 \mathrm{~kg} / \mathrm{cm}^{2}$. Komposisi bahan baku dengan berbagai variasi tekanan kempa yang menghasilkan keteguhan tekan tertinggi adalah komposisi dengan campuran tempurung kelapa 50\% dan 70\%. 
Tabel 5. Nilai rata-rata dan hasil uji BNJ keteguhan tekan briket kayu jarak pagar Table 5. Average values and HSD tests of compression strength of Jatropha wood briquette

\begin{tabular}{|c|c|c|c|c|}
\hline $\begin{array}{c}\text { Komposisi } \\
\text { Composition })\end{array}$ & $\begin{array}{c}\text { Tekanan } \\
\text { (Comprssion) } \\
\text { Kg/cm }\end{array}$ & $\begin{array}{c}\text { Kode perlakuan } \\
\text { (Treatments codes }) \\
\text { T }\end{array}$ & $\begin{array}{c}\text { Keteguhan tekan } \\
\text { (Compression strength) } \\
\mathrm{kg} / \mathrm{cm}^{2}\end{array}$ & $\begin{array}{c}\text { Skor } \\
(\text { Score })\end{array}$ \\
\hline A 1 & B 1 & 1 & $576,00 \mathrm{c}$ & 2 \\
& B 2 & 2 & $841,70 \mathrm{de}$ \\
$1070,70 \mathrm{ab}$ & 5,5 \\
& B 3 & 3 & $768,00 \mathrm{e}$ & 6 \\
\hline A 2 & B 1 & 4 & $854,60 \mathrm{de}$ & 1 \\
& B 2 & 5 & $1169,70 \mathrm{a}$ & 2 \\
\hline A 3 & B 3 & 6 & $633,30 \mathrm{f}$ & 4,5 \\
& B 1 & 7 & $752,00 \mathrm{e}$ & 6 \\
& B 2 & 8 & $1118,70 \mathrm{ab}$ & 6 \\
\hline B 3 4 & B 1 & 10 & $608,00 \mathrm{f}$ & 2 \\
& B 2 & 11 & $756,00 \mathrm{e}$ & 2 \\
& B 3 & 12 & $1046,70 \mathrm{bc}$ & 3 \\
\hline A 5 & B 1 & 13 & $606,70 \mathrm{f}$ & 3,5 \\
& B 2 & 14 & $937,30 \mathrm{~cd}$ & 5,5 \\
& B 3 & 15 & $1124,70 \mathrm{ab}$ & 6 \\
\hline
\end{tabular}

Keterangan (Remarks) : Nilai skor total dihasilkan dari perhitungan menurut asumsi nilai skor a $=6$; $\mathrm{b}$ $=5 ; \quad \mathrm{c}=4 ; \mathrm{d}=3 ; \quad \mathrm{e}=2$ dan $\mathrm{f}=1 . \quad \mathrm{A} 1=$ tempurung biji jarak pagar $100 \% ; \mathrm{A} 2=$ tempurung kelapa 100\%; A3 = tempurung biji jarak 50\% dan tempurung kelapa 50\%; A4 $=$ tempurung biji jarak $75 \%$ dan tempurung kelapa $25 \%$; A $5=$ tempurung biji jarak $25 \%$ dan tempurung kelapa $75 \%$. B1 $=$ tekanan $200 \mathrm{~kg} / \mathrm{cm}^{2} ; \mathrm{B} 2=400 \mathrm{~kg} / \mathrm{cm}^{2}$ dan B3 $=600$ $\mathrm{kg} / \mathrm{cm}^{2}$ (Total score achieved based on calculation with assumptions that a score $=6 ; \mathrm{b}=$ $5 ; \mathrm{c}=4 ; \mathrm{d}=3 ; \mathrm{e}=2$ and $\mathrm{f}=1 . \quad \mathrm{A} 1=$ Jatropha seed shell $100 \% ; \mathrm{A} 2=$ Coconut shell $100 \%$; A3 = Jatropha seed shell $:$ coco-shell $=50 \%: 50 \%$; A4 = Jatropha seed shell $:$ cocoshell $=75 \%: 25 \% ;$ A $5=$ Jatropha seed shell $:$ coco-shell $=25 \%: 75 \%$. B1 $=$ compression of $200 \mathrm{~kg} / \mathrm{cm}^{2}, \mathrm{~B} 2=400 \mathrm{~kg} / \mathrm{cm}^{2}$, and B3 $=600 \mathrm{~kg} / \mathrm{cm}^{2}$, respectively).

\section{Sifat fisiko-kimia briket kayu jarak pagar}

Hasil analisis sifat fisiko-kimia briket arang yang dibuat dari campuran kayu jarak pagar dan tempurung kelapa terlihat pada Tabel 6.

Hasil tabulasi menunjukkan kadar air berkisar antara 1,74 - 9,77\%. Hasil uji beda t-test yang memberikan kadar air terendah diperoleh dari bahan baku tempurung kelapa 100\%. Kombinasi bahan baku dan tekanan yang memberikan kadar air terendah diperoleh dari tempurung kelapa 100\% pada tekanan $200 \mathrm{~kg} / \mathrm{cm}^{2}$. Kadar zat terbang berkisar antara 16,63 $25,00 \%$. Hasil uji beda t-test yang memberikan kadar zat terbang terendah diperoleh dari 
campuran tempurung kelapa 25\%. Kombinasi bahan baku dan tekanan yang memberikan kadar zat terbang terendah diperoleh dari campuran tempurung kelapa 25\% pada tekanan 600 $\mathrm{kg} / \mathrm{cm}^{2}$. Kadar abu berkisar antara 2,11 - 12,83\%. Hasil uji beda t-test yang memberikan kadar abu terendah diperoleh dari bahan baku tempurung kelapa 100\%. Kombinasi bahan baku dan tekanan yang memberikan kadar abu terendah diperoleh dari tempurung kelapa 100\% pada tekanan $400 \mathrm{~kg} / \mathrm{cm}^{2}$. Kadar karbon terikat berkisar antara 62,17-79,80\%. Hasil uji beda t-test yang memberikan kadar karbon terikat tertinggi diperoleh dari bahan baku tempurung kelapa $100 \%$. Kombinasi bahan baku dan tekanan yang memberikan kadar karbon terikat tertinggi diperoleh dari tempurung kelapa 100\% pada tekanan $400 \mathrm{~kg} / \mathrm{cm}^{2}$. Nilai kalor berkisar antara 5014 - $6846 \mathrm{kal} / \mathrm{g}$. Hasil uji beda t-test yang memberikan nilai kalor tertinggi diperoleh dari bahan baku tempurung kelapa 100\%. Kombinasi bahan baku dan tekanan yang memberikan nilai kalor tertinggi diperoleh dari tempurung kelapa 100\% pada tekanan $200 \mathrm{~kg} / \mathrm{cm}^{2}$.

\section{Kualitas Briket Arang Menurut Standar}

Untuk dapat menilai kualitas briket arang dari tempurung biji jarak dan kayu jarak secara objektif, maka kualitas briket yang dihasilkan penelitian ini dibandingkan dengan standar. Briket arang yang dibandingkan dengan standar hanya briket arang yang menggunakan bahan baku tempurung biji atau kayu jarak 100\% (B 100/0) dan bahan tersebut dicampur dengan 50\% tempurung kelapa (B 50/50).

Tabel 7 menunjukkan, bahwa beberapa sifat telah memenuhi standar Jepang yaitu : keteguhan tekan, kadar air, zat terbang, karbon terikat (kecuali tempurung biji jarak B 100/0). Sifat yang tidak memenuhi standar adalah : kerapatan, kadar abu dan nilai kalor (kecuali kayu jarak B 50/50).

Apabila dibandingkan antara briket yang dibuat dari tempurung biji dan kayu jarak pagar murni tanpa dicampur dengan tempurung kelapa, maka briket dari tempurung biji lebih tinggi di dalam kerapatan $\left(0,21 \mathrm{~g} / \mathrm{cm}^{2}\right)$ dan keteguhan tekan $\left(1820 \mathrm{~kg} / \mathrm{cm}^{2}\right)$, tetapi lebih rendah dalam kadar air (1,7\%), karbon terikat $(56,85 \%)$ dan nilai kalor $(4855 \mathrm{kal} / \mathrm{g})$. Briket dari kayu jarak pagar lebih tinggi di dalam kadar air (5,87\%), karbon terikat $(66,01 \%)$ dan nilai kalor $(5750 \mathrm{kal} / \mathrm{g})$, tetapi lebih rendah dalam kerapatan $\left(0,16 \mathrm{~g} / \mathrm{cm}^{2}\right)$ dan keteguhan tekan $(1070,7$ $\left.\mathrm{kg} / \mathrm{cm}^{2}\right)$. 
Tabel 6. Nilai rata-rata sifat fisiko-kimia briket arang dari kayu jarak pagar Table 6. Average values of physico chemical of Jatropha wood-charcoal briquette

\begin{tabular}{|c|c|c|c|c|c|c|}
\hline $\begin{array}{c}\text { Komposisi } \\
\text { (Composition) } \\
\text { A }\end{array}$ & $\begin{array}{c}\text { Tekanan } \\
\text { (Compression) } \\
\mathrm{kg} / \mathrm{cm}^{2} \\
\mathrm{~B}\end{array}$ & $\begin{array}{c}\text { Kadar air } \\
\text { (Moisture) } \\
\%\end{array}$ & $\begin{array}{c}\text { Zat terbang } \\
\text { (Volatile) } \\
\%\end{array}$ & $\begin{array}{c}\text { Kadar abu } \\
(A s h) \\
\%\end{array}$ & $\begin{array}{c}\text { Karbon } \\
\text { terikat } \\
\text { (F. carbon) } \\
\%\end{array}$ & $\begin{array}{l}\text { Nilai kalor } \\
\text { (Calorific } \\
\text { val.), cal/g }\end{array}$ \\
\hline A 1 & $\begin{array}{l}\text { B } 1 \\
\text { B } 2 \\
\text { B } 3\end{array}$ & $\begin{array}{l}5,87 \\
6,07 \\
8,16\end{array}$ & $\begin{array}{l}25,00 \\
20,97 \\
22,19\end{array}$ & $\begin{array}{l}12,83 \\
12,14 \\
11,80\end{array}$ & $\begin{array}{l}62,17 \\
65,89 \\
66,01\end{array}$ & $\begin{array}{l}5250 \\
5191 \\
5014\end{array}$ \\
\hline Rata-rata: & & 6,07 & 22,39 & 12,25 & 61,69 & 5151 \\
\hline A 2 & $\begin{array}{l}\text { B } 1 \\
\text { B } 2 \\
\text { B } 3\end{array}$ & $\begin{array}{l}1,74 \\
2,21 \\
3,15\end{array}$ & $\begin{array}{l}19,76 \\
19,09 \\
20,06\end{array}$ & $\begin{array}{l}2,97 \\
2,11 \\
3,05\end{array}$ & $\begin{array}{l}77,27 \\
79,80 \\
76,89\end{array}$ & $\begin{array}{l}6846 \\
6766 \\
6601\end{array}$ \\
\hline Rata-rata: & & 2,36 & 19,20 & 2,71 & 77,98 & 6731 \\
\hline A 3 & $\begin{array}{ll}\text { B } & 1 \\
\text { B } & 2 \\
\text { B } & 3\end{array}$ & $\begin{array}{l}7,00 \\
8,56 \\
5,65\end{array}$ & $\begin{array}{l}22,08 \\
18,54 \\
20,45\end{array}$ & $\begin{array}{l}11,46 \\
10,84 \\
10,74\end{array}$ & $\begin{array}{l}66,46 \\
70,62 \\
68,81\end{array}$ & $\begin{array}{l}6308 \\
6276 \\
6252\end{array}$ \\
\hline Rata-rata: & & 7,07 & 20,35 & 11,01 & 68,63 & 6278 \\
\hline A 4 & $\begin{array}{l}\text { B } 1 \\
\text { B } 2 \\
\text { B } 3\end{array}$ & $\begin{array}{l}5,91 \\
5,99 \\
6,09\end{array}$ & $\begin{array}{l}20,35 \\
18,29 \\
16,63\end{array}$ & $\begin{array}{c}11,00 \\
10,09 \\
9,67\end{array}$ & $\begin{array}{l}68,65 \\
71,62 \\
73,74\end{array}$ & $\begin{array}{l}6151 \\
6131 \\
6122\end{array}$ \\
\hline Rata-rata: & & 5,99 & 18,42 & 10,25 & 71,33 & 6134 \\
\hline A 5 & $\begin{array}{ll}\text { B } & 1 \\
\text { B } & 2 \\
\text { B } & 3\end{array}$ & $\begin{array}{l}8,74 \\
9,77 \\
5,42\end{array}$ & $\begin{array}{l}20,37 \\
16,76 \\
18,05\end{array}$ & $\begin{array}{l}7,09 \\
6,89 \\
5,63\end{array}$ & $\begin{array}{l}72,54 \\
76,35 \\
76,32\end{array}$ & $\begin{array}{l}6673 \\
6672 \\
6552\end{array}$ \\
\hline Rata-rata: & & 7,97 & 18,39 & 6,53 & 75,07 & 6632 \\
\hline
\end{tabular}

Keterangan (Remarks) : A1 = kayu jarak pagar 100\%; A2 = tempurung kelapa 100\%; A3 = kayu jarak pagar 50\% dan tempurung kelapa 50\%; A4 = kayu jarak pagar 75\% dan tempurung kelapa $25 \%$; A5 = kayu jarak pagar 25\% dan tempurung kelapa 75\%. B1 = tekanan $200 \mathrm{~kg} / \mathrm{cm}^{2}$; $\mathrm{B} 2=400 \mathrm{~kg} / \mathrm{cm}^{2}$ dan B3 $=600 \mathrm{~kg} / \mathrm{cm}^{2}$ (A1 = Jatropha seed shell $100 \% ;$ A2 $=$ Coconut shell 100\%; A3 = Jatropha seed shell: coco-shel l $=50 \%: 50 \% ; A 4=$ Jatropha seed shell: coco-shell $=75 \%$ $: 25 \% ; A 5=$ Jatropha seed shell : coco-shell $=25 \%: 75 \%$. B1 = compression of $200 \mathrm{~kg} / \mathrm{cm}^{2} ; B 2=$ $400 \mathrm{~kg} / \mathrm{cm}^{2}$ and $B 3=600 \mathrm{~kg} / \mathrm{cm}^{2}$, respectively). 
Tabel 7. Kualitas briket arang dari tempurung biji dan kayu jarak pagar dibanding standar

Table 7. Quality of charcoal briquette from Jatropha's seed shell and wood compared to the standard

\begin{tabular}{|c|c|c|c|c|c|}
\hline \multirow{2}{*}{$\begin{array}{l}\text { Parameter } \\
\text { (Parametric) }\end{array}$} & \multicolumn{2}{|c|}{$\begin{array}{l}\text { Tempurung biji jarak } \\
\text { (Jatropha seed shell) }\end{array}$} & \multicolumn{2}{|c|}{$\begin{array}{c}\text { Kayu jarak } \\
\text { (Jatropha wood) }\end{array}$} & \multirow{2}{*}{$\begin{array}{c}\begin{array}{c}\text { Standar } \\
\text { (Standard) }\end{array} \\
\text { Jepang }\end{array}$} \\
\hline & B $100 / 0$ & B $50 / 50$ & B $100 / 0$ & B $50 / 50$ & \\
\hline $\begin{array}{l}\text { Kerapatan (Density) } \\
\mathrm{g} / \mathrm{cm}^{2}\end{array}$ & 0,21 & 0,21 & 0,16 & 0,18 & $0,90-1,00$ \\
\hline $\begin{array}{l}\text { Keteguhan tekan } \\
\text { (Compression strength), } \\
\mathrm{kg} / \mathrm{cm}^{2}\end{array}$ & 1820 & 1910 & 1070 & 118 & $60-65$ \\
\hline Kadar air (Moisture), $\%$ & 1,74 & 1,55 & 5,87 & 5,65 & $6-8$ \\
\hline Kadar abu (Ash), \% & 16,40 & 12,80 & 11,80 & 10,70 & $3-6$ \\
\hline $\begin{array}{l}\text { Zat terbang } \\
(\text { Vol. matter }), \%\end{array}$ & 19,09 & 23,70 & 20,90 & 18,50 & $15-30$ \\
\hline $\begin{array}{l}\text { Karbon terikat } \\
(\text { F. carbon }), \%\end{array}$ & 57,40 & 65,40 & 66,01 & 70,60 & $60-80$ \\
\hline $\begin{array}{l}\text { Nilai kalor } \\
\text { (Calorific value), } \mathrm{kal} / \mathrm{g}\end{array}$ & 4855 & 5727 & 5250 & 6276 & $6000-7000$ \\
\hline
\end{tabular}

\section{KESIMPULAN DAN SARAN}

1. Briket yang dibuat dari tempurung biji jarak pagar (100\%) lebih tinggi di dalam kerapatan dan keteguhan tekan, tetapi lebih rendah di dalam kadar air, karbon terikat dan nilai kalor briket kayu jarak (100\%). Briket kayu jarak pagar (100\%) sebaliknya lebih tinggi dalam kadar air, karbon terikat dan nilai kalor, tetapi lebih rendah dalam kerapatan dan keteguhan tekan dari briket tempurung biji jarak pagar.

2. Pencampuran dengan tempurung kelapa dapat meningkatkan karbon terikat dan nilai kalor briket dari tempurung biji jarak, serta meningkatkan kerapatan dan keteguhan tekan briket dari kayu jarak pagar.

3. Untuk briket dari tempurung biji jarak, kerapatan tertinggi diperoleh dari bahan baku tempurung biji jarak 100\% dengan tekanan kempa $600 \mathrm{~kg} / \mathrm{cm}^{2}$, tempurung kelapa 100\% dengan tekanan kempa $600 \mathrm{~kg} / \mathrm{cm}^{2}$ dan campuran tempurung kelapa 50\% dengan tekanan kempa $600 \mathrm{~kg} / \mathrm{cm}^{2}$. Untuk briket dari kayu jarak pagar, kerapatan tertinggi diperoleh dari bahan baku tempurung kelapa 100\% dengan tekanan kempa $600 \mathrm{~kg} / \mathrm{cm}^{2}$.

4. Untuk briket dari tempurung biji jarak, keteguhan tekan tertinggi diperoleh dari bahan baku tempurung biji jarak 100\% dengan tekanan kempa $600 \mathrm{~kg} / \mathrm{cm}^{2}$, campuran dengan 
tempurung kelapa 50\% pada tekanan kempa $400 \mathrm{dan} 600 \mathrm{~kg} / \mathrm{cm}^{2}$, serta campuran dengan tempurung kelapa 75\% pada tekanan kempa $600 \mathrm{~kg} / \mathrm{cm}^{2}$. Untuk briket dari kayu jarak pagar, keteguhan tekan tertinggi diperoleh dari bahan baku tempurung biji jarak 100\% dengan tekanan kempa $600 \mathrm{~kg} / \mathrm{cm}^{2}$, komposisi dengan campuran tempurung kelapa 50\% pada tekanan 400 dan $600 \mathrm{~kg} / \mathrm{cm}^{2}$, serta komposisi dengan campuran tempurung kelapa $75 \%$ pada tekanan $600 \mathrm{~kg} / \mathrm{cm}^{2}$.

5. Beberapa sifat fisiko-kimia telah memenuhi Standar Jepang yaitu : keteguhan tekan, kadar air, zat terbang dan karbon terikat (kecuali tempurung biji jarak B 100/0). Sifat fisikokimia yang tidak memenuhi standar : kerapatan, kadar abu dan nilai kalor (kecuali kayu jarak B 50/50).

6. Perlu dilakukan penelitian lebih lanjut mengenai peningkatan kualitas briket arang dari tempurung dan kayu jarak pagar dengan menitikberatkan pada aspek kadar perekat yang digunakan.

\section{DAFTAR PUSTAKA}

Abdullah, K. 2002. Biomass Energy Potential and Utilization in Indonesia. Institut Pertanian Bogor.

ASTM. 1959. ASTM Standard. Coal and Coke D-5. American Society for Testing and Materials. Philadephia.

. 1984. ASTM Standard. Laboratory Sampling and Analysis Coal and Coke. American Society for Testing and Materials. Philadephia.

Indarti. 2001. Country Paper : Indonesia. Regional Seminar on Commercialization of Biomass Technology, 4 - 8 June, Guangzhou. China.

Lubis, A. dan A. Sugiyono. 1996. Overview of energy planning in Indonesia. Technical Comittee Meeting to Asses and Compare the Potential Rule of Nuclear Power and Other Options in Alleviating Health and Environental Impacts from Electricity Generation, 14 - 16 October, Vienna, Austria.

Pari, G. 2002. Teknologi alternatif pemanfaatan limbah industri pengolahan kayu. Makalah Falsafah Sains. Program Pasca Sarjana IPB. Bogor.

Sa'id, E.G. 1996. Penanganan dan pemanfaatan limbah kelapa sawit. Trubus Agriwidya. Bogor.

Steel, D.L and J.H. Torrie. 1995. Prinsip dan Prosedur Statistik. Terjemahan, Gramedia. Jakarta.

Sudradjat, R. 1983. Pengaruh bahan baku, jenis perekat dan tekanan kempa terhadap kualitas briket arang. Laporan Penelitian Hasil Hutan No. 165. Pusat Penelitian Hasil Hutan. Bogor.

Anggorowati dan D. Setiawan. 2004. Pembuatan arang aktif dari kayu jarak pagar (Jatopha curcas L.). Jurnal Penelitian Hasil Hutan. 23(4): 299 - 315. Pusat Penelitian dan Pengembangan Hasil Hutan. Bogor. 